\title{
Kesadaran dan Pengetahuan untuk Penanganan Awal Anak Berkebutuhan Khusus di Lembaga PAUD Pesanggrahan Jakarta
}

\author{
Siti Rahmawati ${ }^{1}$, Masni Erika Firmiana ${ }^{2}$, Rochimah Imawati ${ }^{3}$ \\ ${ }^{1,2,3}$ Program Studi Psikologi, Fakultas Psikologi dan Pendidikan, Universitas Al Azhar Indonesia, \\ Kompleks Masjid Agung Al Azhar, Jl. Sisingamangaraja, Kebayoran Baru Jakarta Selatan, 12110
}

Penulis untuk Korespondensi/E-mail: siti_rahmawati@uai.ac.id

Abstrak - Lembaga Pendidikan Anak Usia Dini (PAUD) saat ini sudah semakin tersebar di seluruh Indonesia. Begitu pentingnya PAUD, sehingga menjadi salah satu tujuan penting dalam pembangunan di Indonesia. Seperti tercantum dalam Undang-Undang Dasar 1945 pasal 31 yang menyebutkan bahwa setiap warga negara berhak memperoleh pendidikan (Abdurrachman, 1994:2) termasuk juga anak-anak. Tidak hanya anak-anak yang berada dalam kondisi normal, bahkan juga anak yang memiliki keterbatasan atau biasa disebut Anak Berkebutuhan Khusus (ABK). Sayangnya belum semua pendidik PAUD memiliki pengetahuan dan keterampilan dasar untuk mengenali dan menangani ABK dengan benar. Untuk perlu pelatihan untuk meningkatkan pengetahuan dan keterampilan tersebut.

Suran \& Rizzo (dalam Mangunsong, 2008:3) menyatakan bahwa anak yang tergolong luar biasa atau memiliki kebutuhan khusus adalah anak yang secara signifikan berbeda dalam beberapa dimensi yang penting dari fungsi kemanusiaannya. Intervensi sosial didefinisikan sebagai tindakan yang bertujuan untuk membantu orang per orangan atau kelompok, atau keluarga, atau komunitas dalam konteks kehidupan sosial (Hardjomarsono, 2007: 1.4). Model evaluasi Kirkpatrick adalah model evaluasi pelatihan yang menggunakan empat level dalam mengkategorikan hasil-hasil pelatihan. Empat level tersebut adalah level reaksi, pembelajaran, perilaku dan hasil. (1959, dalam Kirkpatrick, 2006)

Metode yang digunakan adalah kuantitatif, dengan menggunakan model evaluasi pelatihan KirkPatrick, dan pre-post treatment. Sebelum pelaksanaan pelatihan, para peserta akan diberikan pre-test dan setelah kegiatan, para peserta akan mengerjakan post test. Sumber datanya adalah para pendidik PAUD dalam lingkungan HIMPAUDI Kecamatan Pesanggrahan yang mengikuti kegiatan pelathan ini.

Berdasar hasil Pre dan Post test diketahui bahwa persentase mean pre test adalah $68,78 \%$, artinya nilai rata-rata pengetahuan peserta sebelum pelatihan adalah adalah 68, 78, sementara diperoleh hasil post test sebesar $90,68 \%$ yang berarti bahwa nilai rata-rata pengetahuan peserta setelah pelatihan adalah 90,68. Hal ini berarti materi yang diberikan dapat diterima dengan sangat baik oleh peserta, terlihat dari peningkatan persentase rata-rata pengetahuan pre test - post test

Kegiatan pelatihan ini dapat disimpulkan berjalan dengan baik. Untuk kegiatan selanjutnya, diharapkan bisa melakukan semua tahapan dari KirkPaatrick, mempertimbangkan kalender akademik PAUD dan dilakukan dalam skala yang lebih besar dan bertahap.

Kata Kunci - Training, Pendidikan Anak Usia Dini, Guru Pendidikan AUD, Anak Berkebutuhan Khusus 
Abstract - Early Childhood Education Institutions (PAUD) is now increasingly spread throughout Indonesia. Once the importance of early childhood, so it becomes one of the important goals in development in Indonesia. As stated in the 1945 Constitution article 31 stating that every citizen is entitled to education (Abdurrachman, 1994: 2) as well as children. Not only children who are in normal condition, even children who have limitations or so-called Children with Special Needs (ABK). Unfortunately not all PAUD educators have the basic knowledge and skills to recognize and handle the crew properly. To need training to improve the knowledge and skills.

Suran \& Rizzo (in Mangunsong, 2008: 3) states that children who are extraordinary or have special needs are children who are significantly different in some important dimensions of their humanitarian function. Social intervention is defined as an act aimed at helping an individual or group, or family, or community in the context of social life (Hardjomarsono, 2007: 1.4). Kirkpatrick's evaluation model is a training evaluation model that uses four levels in categorizing training outcomes. These four levels are the level of reaction, learning, behavior and results. (1959, in Kirkpatrick, 2006).

The method used is quantitative, using the KirkPatrick training evaluation model, and pre-post treatment. Before the training, participants will be given pre-test and after the activity, the participants will do post test. The data source is PAUD educators in HIMPAUDI sub-district Pesanggrahan who follow this pelathan activity. The method used is quantitative, using the KirkPatrick training evaluation model, and pre-post treatment. Before the training, participants will be given pre-test and after the activity, the participants will do post test. The data source is PAUD educators in HIMPAUDI sub-district Pesanggrahan who follow this pelathan activity.

Based on the results of Pre and Post test it is known that the mean pre test percentage is $68.78 \%$, meaning that the average score of participants' knowledge before the training is 68,78 while the post test result is $\mathbf{9 0 . 6 8 \%}$ which means that the mean participants' knowledge after training is 90.68 . This means that the material given is very well received by the participants, as evidenced by the increase in the average percentage of pre - test - post test knowledge This training activity can be concluded to run well. For subsequent activities, it is expected to perform all stages of KirkPaatrick, consider the academic calendar of early childhood and be done on a larger and gradual scale.

Keywords - Training, Early Childhood Education, Early Childhood Teacher, Special Needs Children

\section{PENDAHULUAN}

$\mathrm{L}$ embaga Pendidikan Anak Usia Dini (selanjutnya diistilahkan dengan Lembaga PAUD) saat ini sudah semakin tersebar di seluruh Indonesia. Begitu pentingnya PAUD, sehingga menjadi salah satu tujuan penting dalam pembangunan di Indonesia. Menurut Mendikbud, berdasarkan hasil sensus, saat ini ada 45, 5 juta anak Indonesia berusia 0-9 tahun. Pada saat usia 100 tahun kemerdekaan Indonesia, mereka akan berusia 35-45 tahun sebagai generasi penerus bangsa. Pemerintah harus mempersiapkan mereka sebaik mungkin, terutama memberikan pendidikan untuk anak usia dini

(http://www.kemdikbud.go.id/kemdikbud/berit a/2655).
Mendikbud mempertegas hal tersebut dengan fakta bahwa usia dini merupakan masa keemasan untuk menyiapkan generasi mendatang yang kuat guna pembangunan negara di masa mendatang.

Gerakan promosi pemerintah tentang PAUD baik melalui program kegiatan Kemdiknas maupun sosialisasi Bunda PAUD pun mulai menunjukkan hasil. Deklarasi ibu negara sebagai Bunda PAUD Nasional, sampai dengan adanya Bunda PAUD Propinsi, Kabupaten/Kota serta liputan media massa dan elektronik tentang perlindungan anak mulai menumbuhkan kesadaran masyarakat akan pentingnya PAUD. Saat ini makin banyak orang tua yang memiliki anak usia dini berbondong-bondong mengikutsertakan 
anaknya di lembaga PAUD terdekat dengan tempat tinggalnya.

Hal tersebut dapat dilihat dari data Angka Partisipasi Kasar (APK) keterlibatan PAUD di Indonesia. Saat ini Target Angka Partisipasi Kasar (APK) 75\% pada tahun 2015 yang dimiliki Kementerian Pendidikan dan Kebudayaan sesuai dengan kesepakatan pada Konvensi Dakkar tahun 2000, melalui Program 1 Desa 1 PAUD. Hingga akhir tahun 2013, dari total 77.559 desa se-Indonesia, sebanyak 53.832 desa sudah terlayani PAUD. Target Renstra dan capaian PAUD (3-6 tahun) menghasilkan prestasi yang sangat baik dengan melihat indikator kerja utama APK PAUD secara nasional pada tahun 2012 memiliki target APK 63,60, terealisasikan 63,01\%, tahun 2013 target APK 67,40\%, terealisasikan 69,4\%, sedangkan tahun 2014 Kemdikbud memiliki target capaian APK 72,90\%. Peningkatan APK PAUD tercermin dari jumlah lembaga PAUD yang terus bertambah setiap tahun. Hingga bulan Desember 2013, jumlah lembaga PAUD mencapai 174.367 lembaga se-Indonesia. Dari jumlah tersebut, Taman Kanak-kanak (TK) menempati posisi teratas, atau sebanyak 74.487 TK, lalu diikuti kelompok bermain sebanyak 70.477 dan satuan PAUD sejenis mencapai 26.269 lembaga. Hingga akhir tahun 2014 tercatat ada 3.134 Taman Penitipan Anak.

(http://www.kemdikbud.go.id/kemdikbud/berit a/2060, dan http://republiknews.com/apkpaud-setiap-tahun-terus-meningkat/).

Sebagaimana tercantum dalam UndangUndang Dasar 1945 pasal 31 yang menyebutkan bahwa setiap warga negara berhak memperoleh pendidikan (Abdurrachman, 1994:2) termasuk juga anakanak. Tidak hanya anak-anak yang berada dalam kondisi normal, bahkan juga anak yang memiliki keterbatasan atau biasa disebut Anak Berkebutuhan Khusus (ABK). Para ABK memiliki hak yang sama untuk mengenyam pendidikan yang baik sejak usia dini hingga dewasa.

Untuk menyatakan bahwa seorang anak memiliki kebutuhan khusus bukanlah suatu hal yang cepat dan mudah. Diperlukan sebuah pemeriksaan yang intensif dan waktu yang cukup lama untuk menegakkan diagnos bahwa seorang anak berada dalam kategori memiliki kebutuhan khusus. Penetapan ini pun memerlukan kerjasama dari tenaga-tenaga profesional, termasuk didalamnya dokter spesialis anak, perawat, terapis, bahkan psikolog. Kerjasama yang menyeluruh dari berbagai profesi memungkinkan ABK memperoleh penanganan yang tepat dan sesuai dengan kondisinya.

Saat ini, jumlah ABK di Indonesia cenderung meningkat. Berdasarkan hasil survey BPS pada tahun 2005, diperkirakan dari 22,8 juta penduduk dengan rentang usia 5-14 tahun, 4,2 juta atau 10 persen diantaranya merupakan anak berkebutuhan khusus. Angka tersebut diyakini Kepala BKKBN Dr Fasli Jalal sudah meningkat tajam dalam beberapa tahun terakhir ini, mengingat makin mudahnya kita menemukan anak-anak dengan gangguan tumbuh kembang baik secara fisik, intelektual, emosi maupun sosial ditengah masyarakat (http://poskotanews.com/2013/07/19/jumlahanak-berkebutuhan-khusus-meningkat).

Lembaga Pendidikan Anak Usia Dini (PAUD) adalah lembaga yang memiliki arti penting bagi anak usia dini, termasuk ABK. Di dalam PAUD, para ABK memerlukan penanganan khusus sehingga dapat sesuai dengan keterbatasan yang mereka miliki (Panduan Penanganan Anak Berkebutuhan Khusus Bagi Pendamping (Orang tua, Keluarga, dan Masyarakat), Kementerian Pemberdayaan Perempuan dan Perlindungan Anak Republik Indonesia, Jakarta, 2013). Di sisi lain, berdasarkan NSPK Juknis Penyelenggaraan Pos PAUD dari Kementerian Pendidikan dan Kebudayaan (2013) jelas tercantum bahwa penyelenggara Program PAUD harus menerapkan sejumlah prinsip PAUD, a.l berorientasi pada kebutuhan si anak, sesuai dengan perkembangan anak dan sesuai dengan keunikan tiap individu. Dengan demikian, seharusnya saat di PAUD, AUD yang merupakan $\mathrm{ABK}$ perlu penanganan khusus dari pendidik PAUD.

Sayangnya tidak semua lembaga PAUD memiliki tenaga ahli untuk penanganan AUD yang ABK. Ditambah kebutuhan lagi dengan kondisi bahwa tidak semua pendidik PAUD memiliki pengetahuan yang memadai untuk mengenali dan memberikan pendidikan yang tepat untuk ABK. Terkadang AUD yang 
memiliki keterbatasan atau kebutuhan khusus tidak diterima di lembaga PAUD karena dianggap aneh atau bahkan dicap "bodoh" oleh pendidik PAUD itu sendiri (http://edisicetak.joglosemar.co/berita/pendidi kan-anak-berkebutuhan-khusus-249000orang-belum-tersentuh-10611.html).

Sebenarnya hal ini tidak terlalu mengejutkan. Berdasar riset Fitriani dkk (2011) terungkap bahwa rata-rata pendidik PAUD menjadikan pekerjaan pendidik sebagai pekerjaan sambilan. Hal ini dapat dilihat dari latar pekerjaan sesungguhnya yang bervariasi, seperti ibu rumah tangga, pedagang, sales asuransi, pegawai mall, baru lulus sekolah (fresh graduates), bahkan perawat di klinik gigi. Selain itu, pada umumnya pendidik PAUD tersebut memiliki latar belakang pendidikan SMA sederajat (padahal seharusnya pendidikan Diploma). Keragaman pendidikan dan pekerjaan lainnya ini selain menjadi kekurangan juga kelebihan, karena membuktikan semakin baiknya kesadaran masyarakat dalam hal menghimpun sumber daya dan sumber dana dari masyarakat sendiri. Hal ini juga mengindikasikan kesadaran masyarakat yang semakin baik.

Namun dengan kondisi pendidik di lembaga PAUD seperti ini tentu dapat diperkirakan bagaimana penanganan ABK di lembaga PAUD. Berdasar observasi awal, tim menemukan sejumlah kondisi, seperti (1) pendidik PAUD tidak mengetahui dan tidak memahami kondisi ABK, bahkan pendidik PAUD terlihat bingung dengan kondisi ABK yang memiliki sindrom autism, hiperaktif, kemampuan membedakan huruf yang belum optimal (misal, belum mampu membedakan huruf "b", "d", dan "p ) (lihat Sanityasa, 2014) (2) Pendidik PAUD menggabungkan ABK dengan anak non ABK, dan (3) Pendidik PAUD tidak memberikan treatment yang seharusnya diterima oleh ABK. Hal lain yang dapat diobservasi adalah adanya labelling terhadap si anak dengan cap "bodoh", "nakal" dan istilah buruk lain yang sejenis. Hal ini akan berujung pada kondisi si anak yang tidak dapat bertumbuh kembang dengan baik. Padahal, menurut Kepala BKKBN Pusat, DR. Fasli Djalal, jika anak berkebutuhan khusus ditangani sejak awal, maka segala bakat dan kemampuannya bisa dieksplorasi dan itu akan menyelamatkan masa depannya (http://poskotanews.com/2013/07/20/kenalianak-berkebutuhan-khusus-sejak-dini/).

"Pengabaian" karena ketidaktahuan pendidik PAUD ini juga merupakan pelanggaran terhadap hak anak untuk memperoleh pendidikan. Menurut Direktur Pembinaan Pendidikan Luar Biasa Kemdikbud, berdasar data tahun 2010, tercatat ada sekitar 329.000 ABK di seluruh Indonesia, di antaranya hanya 75.000 yang beruntung beroleh pendidikan (http://edisicetak.joglosemar.co/berita/pendidi kan-anak-berkebutuhan-khusus-249000orang-belum-tersentuh-10611.html). Dengan demikian memang dibutuhkan kerjasama banyak pihak. Dalam hal ini ujung tombak adalah guru, untuk dapat menemukenali atau melakukan deteksi dini bahwa AUD mengalami gangguan, selanjutnya dapat mengarahkan orang tua untuk mencari "pertolongan" lanjutan. Untuk dapat memahami dan memberikan perlakuan yang tepat, para pendidik PAUD harus memiliki pengetahuan dan keterampilan yang lebih baik.

\section{KERANGKA TEORI}

\section{Anak Berkebutuhan Khusus}

Istilah Anak Berkebutuhan Khusus (ABK) merupakan istilah yang digunakan untuk menggambarkan kondisi anak yang memerlukan pendidikan khusus dan pelayanan terkait sesuai dengan kondisi dirinya. Istilah ABK merupakan istilah yang dipakai untuk menggantikan penggunaan istilah Anak Luar Biasa (ALB). Istilah ALB memiliki makna yang lebih luas dibandingkan dengan istilah anak cacat atau anak yang menyandang ketunaan (handicapped children) seperti tuna netra, tuna wicara, tuna rungu, tuna grahita atau tuna daksa. Istilah ALB memiliki arti generik, yang didalamnya tercakup anak cacat atau anak yang menyandang ketunaan (Abdurrachman, 1994).

Suran \& Rizzo (dalam Mangunsong, 2008:3) menyatakan bahwa anak yang tergolong luar biasa atau memiliki kebutuhan khusus adalah anak yang secara signifikan berbeda dalam beberapa dimensi yang penting dari fungsi kemanusiaannya. Mereka yang secara fisik, psikologis, kognitif atau sosial terhambat dalam mencapai tujuan-tujuan atau kebutuhan dan potensinya secara maksimal, meliputi 
mereka yang tuli, buta, mempunyai gangguan bicara, cacat tubuh, retasdasi mental, gangguan emosional. Juga anak-anak yang berbakat dengan intelegensi yang tinggi dapat dikategorikan sebagai anak khusus/luar biasa, karena memerlukan penanganan yang terlatih dari tenaga profesioal.

Diungkapkan oleh Kirk dan Gallagher (Abdurrachman, 1994) bahwa Anak luar biasa atau anak berkebutuhan khusus adalah anak yang memiliki kondisi diatas atau dibawah rata-rata atau normal dalam karakteristik mental, kemampuan sensoris, karakteristik neuromotor atau fisik, perilaku social, kemampuan berkomunikasi atau gabungan dari berbagai variabel tersebut. Lebih lanjut, Hallahan \& Kauffman, (2006, dalam Mangunsong 2008:3), menyatakan bahwa dari sudut kebutuhan pendidikan, siswa berkebutuhan khusus adalah mereka yang memerlukan pendidikan khusus dan pelayanan terkait, jika mereka menyadari akan potensi penuh kemanusiaan mereka. Pendidikan khusus diperlukan karena mereka tampak berbeda dari siswa pada umumnya dalam satu atau lebih hal berikut: mereka mungkin memiliki keterbelakangan mental, ketidakmampuan belajar atau gangguan atensi, gangguan emosi atau perilaku, habatan fisik, hambatan berkomunikasi, autism, traumatic brain injury, hambatan pendengaran, hambatan penglihatan atau special gifts or talent. Gearheart (1981, dalam Mangunsong, 2008:3). menyatakan bahwa seorang anak dianggap berkelainan bila memerlukan persyaratan pendidikan yang berbeda dari ratarata anak normal dan untuk dapat belajar secara efektif memerlukan program, pelayanan, fasilitas dan materi khusus

\section{Intervensi Sosial}

Intervensi sosial didefinisikan sebagai tindakan yang bertujuan untuk membantu orang per orangan atau kelompok, atau keluarga, atau komunitas dalam konteks kehidupan sosial mereka (Hardjomarsono, 2007 : 1.4). Johnson (dalam Hardjomarsono, 2007 : 1.4) menyatakan bahwa intervensi sosial adalah :

1. “...tindakan spesifik yang dikerjakan oleh pelaku intervensi yang terkait dengan upaya untuk menimbulkan perubahan"

2. "...sebuah alat yang digunakan oleh pelaku intervensi sosial untuk memecahkan masalah-masalah dengan cara yang rasional."

Berdasar definisi tersebut, terlihat bahwa intervensi sosial bertujuan untuk membantu target mengalami perubahan yang diinginkan. Selain itu, dapat terlihat juga bahwa ada beberapa komponen dalam intervensi sosial : pelaku intervensi, target intervensi, pemecahan masalah, dan perubahan. Dalam kegiatan ini, pelaku intervensi adalah tim peneliti UAI, target intervensi adalah para pendidik PAUD, pemecahan masalahnya adalah peningkatan informasi dan keterampilan dalam mengenali dan menangani ABK di lembaga PAUD. Perubahan yang diharapkan adalah adanya pemahaman baru para guru tentang penanganan $\mathrm{ABK}$ di lembaga PAUDnya masing-masing.

\section{Manfaat Intervensi sosial}

Setelah target beroleh intervensi, diharapkan target akan mengalami perubahan :

1. Target dapat beroleh kembali keberfungsian sosial selaku anggota masyarakat yang baik.

2. Memperoleh kemampuan untuk mengatasi gangguan yang dihadapi target.

3. Meningkatkan kemampuan mengatasi masalah dlam kehidupannya dengan teknin penyelesaian yang baik.

4. Lebih mampu menjalankan perananperanan yang baru sesuai dengan perkembangan dirinya sehingga gangguan serupa dapat dicegah supaya tidak berulang lagi

Upaya intervensi dalam konteks sosial dapat dipilah sebagai berikut :

1. Memberikan bantuan untuk memulihkan keberfungsian sosial seseorang, orangorang, keluarga, kelompok atau komunitas sebagai warga keluarga, warga kelompok atau komunitas yang layak.

2. Mencakup kegiatan-kegiatan lain untuk mengatasi atau mencegah timbulnya masalah-masalah

3. Mencapai tujuan perbaikan sosial

4. Membantu atau mendorong target untuk mengalami perubahan atau perkembangan yang diinginkan.

Berdasar 4 (empat) hal tersebut di atas, tujuan intervensi sosial dapat dipilah lagi menjadi :

1. Bersifat kuratif dan korektif (butir 1),

2. Preventif (butir 2) 
3. Promotif (butir 3)

4. Pengembangan atau developmental (butir 4), jika intervensi dilakukan dengan kemungkinan untuk mengembangkan diri target.

Berdasarkan riset awal, tujuan intervensi pada kegiatan ini adalah pada butir 1-3

\section{Metode Intervensi Sosial}

Metode intervensi sosial yang sering digunakan adalah sebagai berikut (Hardjomarsono, 2007: 1.10):

1. Praktik mikro, yang terutama memusatkan perhatian pada pelayanan langsung pada orang per orang berdasarkan layanan kasus demi kasus. Praktik mikro umumnya dilakukan di badan-badan intervensi klinis

2. Praktik Mezzo, ditujukan untuk pemberian bantuan bagi keluarga dan kelompok kecil. Kegiatan pada jenjang ini mencakup memberikan layanan komunikasi, mediasi, bernegosiasi, mendidik dan mengajak orang-orang bertemu untuk bersama-sama memecahkan masalah yang dihadapi

3. Praktik makro, yang diarahkan untuk mendatangkan perbaikan dan perubahanperubahan dalam komunitas (masyarakat). kegiatan semacam ini meliputi beberapa tipe intervensi seperti aksi politik (misalnya penyusunan undang-undang baru), pembangunan masyarakat, gerakan pendidikan masyarakat, administrasi badan sosial yang mempunyai layanan yang luas dan badan-badan kesejahteraan publik lainnya.

Berdasarkan observasi awal, metode intervensi sosial yang akan dilakukan adalah pada praktik Mezzo. Pelaksanaan Intervensi sosial, diawali dengan adanya masalah sosial yang harus dipecahkan atau diselesaikan. Setelah pelaku intervensi mengidentifikasi permasalahan, akan dirancang suatu kegiatan perubahan yang terencana. Kegiatan perubahan terencana ada yang dibuat sendiri oleh pelaku intervensi, ada yang kolaborasi antara pelaku intervensi dengan target intervensi. Selanjutnya, kegiatan intervensi dapat dimulai setelah adanya assessmen terkait target intervensi. Selanjutnya pelaku intervensi akan melaksanakan kegiatan yang sudah dirancang dengan menerapkan sejumlah teknik-teknik intervensi. Bagian ini disebut dengan proses pemberian pengaruh. Untuk dapat melakukan pemberian pengaruh secara terampil, seorang pelaku intervensi perlu memiliki keterampilan dalam hal (Hardjomarsono, 2007: 6.3):

1. Pengetahuan dan keahlian/kepakaran

2. Sumber-sumber pelayanan material

3. Kewenangan

4. Status dan reputasi

5. Kharisma dan daya tarik pribadi

6. Kontrol terhadap arus informasi

7. Relasi -relasi yang telah mapan

Sementara itu, untuk melaksanakan tujuh hal tersebut dengan baik, harus dilakukan dengan empat cara utama (Hardjomarsono, 2007: 6.3):

1. Pemaksaan (inducement)

2. Persuasi

3. Penggunaan relasi

4. Penggunaan lingkungan.

Dalam kegiatan ini, cara yang digunakan adalah persuasi, penggunaan relasi (para pakar di bidang psikologi klinis dan PAUD), dan lingkungan (sarana kesehatan seperti Puskesmas)

\section{Model Evaluasi Pelatihan}

Model evaluasi Kirkpatrick merupakan model evaluasi pelatihan yang dikembangkan pertama kali oleh Donald L. Ki rkpatrick (1959, dalam Kirkpatrick, 2006) dengan menggunakan empat level dalam mengkategorikan hasil-hasil pelatihan. Empat level tersebut adalah level reaksi, pembelajaran, perilaku dan hasil.

Level pertama adalah reaksi. Reaksi dilakukan untuk mengukur tingkat reaksi yang didisain agar mengetahui opini dari para peserta pelatihan mengenai program pelatihan. Evaluasi reaksi ini sama halnya dengan mengukur tingkat kepuasan peserta pelatihan. Untuk mengukur tingkat kepuasan terhadap pelatihan ini, biasanya diiringi dengan isian tentang instruktur /pelatih, fasilitas pelatihan, materi pelatihan, hingga konsumsi yang disediakan selama pelatihan.

Level kedua adalah pembelajaran. Level ini dilakukan untuk mengetahui sejauh mana daya serap peserta program pelatihan pada materi pelatihan yang telah diberikan. Evaluasi pada level ini, untuk mengetahui sejauh mana daya serap peserta program pelatihan pada materi pelatihan yang telah diberikan, dan juga 
dapat mengetahui dampak dari program pelatihan yang diikuti para peserta dalam hal peningkatan knowledge, skill dan attitude mengenai hal-hal yang dipelajari dalam pelatihan. Oleh karena itu diperlukan tes guna untuk mengetahui kesungguhan apakah para peserta mengikuti dan memperhatikan materi pelatihan yang diberikan. Data evaluasi diperoleh dengan membandingkan hasil dari pengukuran sebelum pelatihanatau tes awal (pre-test) dan sesudah pelatihan atau tes akhir (post-test).

dari setiap peserta. Pertanyaan

pertanyaan disusun sedemikian rupa sehingga mencakup semua isi materi dari pelatihan.

Level ketiga adalah perilaku. Pada level ini diharapkan setelah mengikuti pelatihan terjadi perubahan tingkah laku peserta pelatihan dalam melakukan pekerjaannya. Selain itu juga untuk mengetahui apakah pengetahuan, keahlian dan sikap yang baru sebagai dampak dari program pelatihan, benar-benar dimanfaatkan dan diaplikasikan di dalam perilaku kerja sehari-hari dan berpengaruh secara signifikan terhadap peningkatan kinerja/ kompetensi di unit kerjanya masing-masing.

Level terakhir adalah result (hasil), yang dilakukan untuk menguji dampak pelatihan terhadap kelompok kerja atau organisasi secara keseluruhan. Hasil akhir tersebut meliputi, peningkatan hasil produksi dan kualitas, penurunan harga, peningkatan penjualan. Tujuan dari pengumpulan informasi pada level ini adalah untuk menguji dampak pelatihan terhadap kelompok kerja atau organisasi secara keseluruhan. Sasaran pelaksanaan pelatihan adalah hasil yang nyata yang

akan disumbangkan kepada perusahaan /lemba ga sebagai pihak yang berkepentingan. Walaupun tidak memberikan hasil yang nyata bagi perusahaan/ lembaga dalam jangka

pendek, bukan berarti program pelatihan tersebut tidak berhasil. Ada kemungkinan berbagai faktor yang mempengaruhi hal tersebut, dan sesungguhnya hal tersebut dapat dengan segera diketahui penyebabnya, sehingga dapat pula sesegera mungkin diperbaiki. Meski Kirkpatrick (2006) menjelaskan ada 4 level, namun dalam kegiatan ini tim hanya menerapkan pada level 2 (pengetahuan). Hal ini terjadi karena keterbatasan waktu, dan pendanaan. Tim hanya melakukan analisis hingga peningkatan pengetahuan

\section{METODE PENELITIAN}

\begin{abstract}
Metode
Metode yang digunakan adalah kuantitatif, dengan menggunakan model evaluasi pelatihan KirkPatrick, dan pre-post treatment. Sebelum pelaksanaan pelatihan, para peserta akan diberikan pre-test dan setelah kegiatan selesai dilakukan, para peserta akan mengerjakan post test.
\end{abstract}

\section{Data dan Sumber Data}

Data dalam kegiatan ini adalah peningkatan pengetahuan dan keterampilan para pendidik PAUD tentang deteksi dini dan penanganan ABK yang akan dilihat dari hasil pre dan post test. Pre dan post test mencakup pengetahuan dan keterampilan para pendidik PAUD terkait penanganan awal ABK sebelum dan sesudah kegiatan pelatihan. Sumber datanya adalah para pendidik PAUD dalam lingkungan HIMPAUDI Kecamatan Pesanggrahan yang mengikuti kegiatan pelathan ini.

\section{Jumlah Sampel}

Jumlah sampel dalam kegiatan ini adalah empat puluh empat (44) orang pendidik PAUD dalam lingkungan HIMPAUDI Kecamatan Pesanggrahan.

\section{Teknik Pengumpulan Data,}

Sugiyono (2013: 194) mengemukakan terdapat tiga teknik pengumpulan data berdasarkan tekniknya yaitu wawancara, angket (kuisioner), dan observasi. Teknik pengumpulan data yang digunakan dalam kegiatan ini adalah angket (kuisioner). Kuesioner sudah disiapkan oleh tim, dan peserta mengisinya sebanyak dua kali yaitu sebelum dan sesudah kegiatan pelatihan.

\section{Metode Analisis Data}

Berdasarkan data yang diperoleh dari angket (kuisioner), selanjutnya akan diolah menggunakan SPSS for windows. Sejalan dengan yang sudah disampaikan sebelumnya, pelatihan ini akan melihat perubahan pengetahuan peserta pelatihan sebelum dan sesudah kegiatan. Untuk itu data yang diperoleh dari pre dan post test tersebut kemudian dianalisis dengan $\mathrm{t}$ - test. 


\section{HASIL DAN PEMBAHASAN}

\section{Profil HIMPAUDI (Nasional dan Kecamatan Pesanggrahan)}

Himpunan pendidik dan tenaga kependidikan anak usia dini Indonesia (Selanjutnya disebut HIMPAUDI) merupakan organisasi profesi yang didirikan pada tanggal 6 Juni 2005 di Jakarta. HIMPAUDI lalu dideklarasikan secara bersama-sama oleh Pendidik Tenaga Kependidikan (PTK) PAUD si Malang, Jawa Timur pada tanggal 31 Agustus 2005.

Sebagai sebuah induk organisasi profesi, HIMPAUDI memiliki visi dan misi yang menjadi landasan dalam organisasi. Visi HIMPAUDI adalah menjadi organisasi professional dan mandiri untuk mewujudkan pendidik dan tenaga kependidikan PAUD yang kompeten, berkualitas dan bermartabat pada tahun 2025. Visi ini lalu diturunkan dalam misi organisasi, yaitu meningkatkan kompetensi PTK PAUD, meningkatkan kualifikasi PTK PAUD, memperjuangkan kesejahteraan PTKK PAUD, menjalin kemitraan untuk meningkatkan kompetensi, kualifikasi, kesejahteraan dan perlindungan serta penghargaan kepada PTK PAUD, meningkatkan kapasitas organisasi dan mendorong pembentukan HIMPAUDI di berbagai wilayah ( $\underline{w w w . h i m p a u d i . o r . i d})$.

Salah satu organisasi HIMPAUDI dalam area wilayah adalah HIMPAUDI Kecamatan Pesanggrahan, Jakarta Selatan. HIMPAUDI Kecamatan Pesanggrahan membawahi 60 lembaga PAUD yang berada di sekitar wilayah Kecamatan Pesanggrahan. Dalam pelaksanaan organisasi, HIMPAUDI kecamatan Pesanggrahan berupaya melakukan koordinasi dan kerjasama dengan pemerintah daerah terkait, termasuk tingkat kota (Jakakrta Selatan), kelurahan, rukun warga (RW) sampai tingkat rukun tetangga (RT)/

\section{Profil Responden/ Peserta Pelatihan}

Responden dalam kegiatan ini adalah guruguru lembaga PAUD yang mewakili setiap PAUD di kecamatan Pesanggrahan. Berdasarkan jumlah lembaga PAUD yang ada, jumlah responden diperkirakan akan mencapai enam puluh (60) orang peserta, ditambah dengan perwakilan pengurus organisasi, diperkirakan jumlah peserta akan mencapai tujuh puluh (70) peserta. Para guru di lembaga-lembaga PAUD ini belum sepenuhnya memiliki pendidikan yang tinggi. Rata-rata pendidikan para guru adalah pendidikan menengah atas (SMA), meskipun ada yang sedang mengikuti perkuliahan strata satu (S1) bahkan ada yang sedang mengikuti program magister (S2). Hal ini sejalan dengan temuan Fitriani, dkk, 2011) bahwa kualifikasi pendidikan sebagian pendidik PAUD masih belum memenuhi standar pemerintah (minimal PGTK/ Sarjana strata 1)

Para guru di lembaga PAUD ini ada yang sudah pernah menangani anak berkebutuhan khusus (ABK), ada juga yang belum. Penanganan terhadap ABK diberikan seadanya dengan pengetahuan yang dimiliki. Melalui kegiatan ini diharapkan para guru memiliki informasi lebih baik untuk menangani ABK.

\section{Pelaksanaan Kegiatan}

Pelaksanaan kegiatan pelatihan ini adalah pada hari Sabtu, 4 April 2015, pukul 08.00 - 15.30 WIB, bertempat di Ruang 006 kampus Universitas Al Azhar Indonesia, Jakarta, dan diikuti oleh empat puluh empat (44) peserta. Jumlah peserta tidak seperti yang diprediksi (70 orang), karena waktu pelaksanaan bertepatan setelah hari libur nasional dan akhir pekan. Ketika peserta tiba di lokasi kegiatan, selain menerima bahan / materi pelatihan, juga mengisi kuesioner (Pre Test) yang disiapkan oleh tim.

\section{Hasil Analisis}

Setelah pelatihan selesai, data mentah dari angket dianalisis dengan t-test menggunakan SPSS for windows. Paired Samples Statistics menunjukkan bahwa persentase mean pre test adalah $68,78 \%$, yang berarti berdasar aitemaitem yang sudah diisi oleh peserta, nilai ratarata pengetahuan peserta adalah 68, 78 . Selanjutnya, terlihat juga bahwa persentase mean post test adalah $90,68 \%$ yang berarti bahwa nilai rata-rata pengetahuan peserta adalah 90,68. Hal ini berarti materi yang diberikan dapat diterima dengan sangat baik oleh peserta, terlihat dari peningkatan persentase rata-rata pengetahuan pre test post test.

Sementara itu, Paired Samples Correlations dan Paired Samples Test menunjukkan bahwa korelasinya $62,9 \%$, artinya korelasi pre test 
dan post post rata-rata tinggi dengan tingkat signifikansi dibawah $0,05 \%$. Lebih jauh hal ini berarti bahwa terjadi peningkatan pengetahuan yang signifikan dari pre test ke post test.

\section{Pembahasan}

Berdasarkan model evaluasi Kirkpatrick (2006) level ke dua adalah pengetahuan. Level ini dilakukan untuk mengetahui sejauh mana daya serap peserta program pelatihan pada materi pelatihan yang telah diberikan. Evaluasi pada level ini, untuk mengetahui sejauh mana daya serap peserta program pelatihan pada materi pelatihan yang telah diberikan, dan juga dapat mengetahui dampak dari program pelatihan yang diikuti para peserta dalam hal peningkatan knowledge, skill dan attitude mengenai hal -hal yang dipelajari dalam pelatihan. Oleh karena itu diperlukan tes guna untuk mengetahui kesungguhan apakah para peserta mengikuti dan memperhatikan materi pelatihan yang diberikan. Data evaluasi diperoleh dengan membandingkan hasil dari pengukuran sebelum pelatihan atau tes awal (pre-test) dan sesudah pelatihan atau tes akhir (post-test).

Berdasar analisis data, terlihat bahwa daya serap para peserta pelatihan (para pendidik PAUD) sangat baik, karena rata-rata persentase mean pre test adalah $68,78 \%$, namun rata-rata persentase mean post test nya mencapai angka 90,68. Ini dapat diartikan bahwa pelatihan berhasil mengubah pengetahuan dan keterampilan para pendidik PAUD HIMPAUDI Kecamatan Pesanggrahan dalam penanganan awal ABK. Ketika Kirkpatrick (2006) menyatakan bahwa masih ada 2 level selanjutnya, namun dalam kegiatan ini berhenti sampai pada tahap 2 karena keterbatasan waktu, juga dana.

Selanjutnya, pelatihan yang sudah dilakukan memberikan dampak pada level mezzo dalam kelompok HIMPAUDI Kecamatan Pesanggrahan (Hardjomarsono, 2007 : 1.10). Praktik Mezzo, ditujukan untuk pemberian bantuan bagi keluarga dan kelompok kecil. Kegiatan pada jenjang ini mencakup memberikan layanan komunikasi, mediasi, bernegosiasi, mendidik dan mengajak orangorang bertemu untuk bersama - sama memecahkan masalah yang dihadapi. Pelatihan yang sudah dilakukan berhasil memberikan bantuan bagi kelompok kecil (dalam hal ini HIMPAUDI Kecamatan Pesanggrahan) dalam mengatasi permasalahan yang mereka hadapi. Kegiatan yang dilakukan untuk intervensi sosial ini berbentuk kegiatan terencana untuk memberikan layanan mendidik (berupa pelatihan) secara bersamasama di suatu tempat (Universitas Al Azhar Indonesia).

Kegiatan pelatihan tersebut dilakukan dalam bentuk pemberian pengaruh. Untuk dapat melakukan pemberian pengaruh secara terampil, seorang pelaku intervensi perlu memiliki keterampilan dalam sejumlah hal (Hardjomarsono, 2007: 6.3), dan untuk melaksanakan tujuh hal tersebut dengan baik, harus dilakukan dengan empat cara utama (Hardjomarsono, 2007: 6.3):

1. Pemaksaan (inducement)

2. Persuasi

3. Penggunaan relasi

4. Penggunaan lingkungan.

Dalam kegiatan ini, cara yang digunakan adalah persuasi, dan penggunaan relasi (para pakar di bidang psikologi klinis dan PAUD). Pembicara dalam kegiatan ini ada dua (2) orang. Pembicara pertama adalah Ibu Nurfadillah, M.Psi, Psikolog, seorang psikolog anak yang juga Praktisi Pendidik PAUD. Pembicara kedua adalah Ibu Risris Rissyanah, $\mathrm{K}$, pernah menjabat sebagai manajer Rumah Autis Cabang Tangerang, dan terakhir sebagai direktur sebuah lembaga yang berfokus pada pendidikan untuk ABK. Pembujukan (persuasif ) dilakukan dengan baik oleh para pembicara, karena mereka memiliki pengetahuan dan keahlian/kepakaran di bidangnya masing-masing terkait tema tema pelatihan. Selain itu para pembicara juga memiliki status dan reputasi yang baik (CV pembicara terlampir). Hasil dari pelatihan memberikan bukti, yang dapat dilihat dari hasil olah data.

\section{KESIMPULAN}

Berdasarkan pembahasan dapat diambil kesimpulan, bahwa pelatihan yang diberikan telah berhasil meningkatkan pengetahuan dan keterampilan pendidik PAUD HIMPAUDI Kecamatan Pesanggrahan. Selain karena pelatihan semacam ini sangat jarang dilakukan, para pembicara yang berkompeten di bidangnya turut memberikan andil. Seperti yang disampaikan oleh (Hardjomarsono, 2007 : 1.10), bahwa perlu orang yang memiliki 
kepakaran/keahlian dalam memberikan persuasi supaya orang lain dapat berubah sesuai dengan perencanaan. Perubahan tersebut sudah dianalisis dengan menggunakan SPSS, dan terbukti bahwa terdapat perubahan pengetahuan yang signifikan, sebelum dan sesudah pelatihan.

Kirkpatrick (2006) menyatakan evaluasi pelatihan dilakukan melalui 4 tahap, namun dalam kegiatan ini hanya 1 tahap. Untuk kegiatan selanjutnya, diharapkan bisa melakukan semua tahap tersebut. Untuk dapat melaksanakan semua tahap tersebut, dibutuhkan dukungan dana yang cukup besar.

Selain itu, persiapan kegiatan perlu dirancang dengan lebih matang, baik dari UAI maupun HIMPAUDI, supaya tidak terjadi pengunduran berulang kali. Salah satu cara untuk mengantisipasinya adalah mempertimbangkan kalender akademik PAUD.

Kegiatan ini adalah kegiatan dasar, namun ternyata sangat memberi manfaat bagi pendidik PAUD, sehingga perlu dibuat kegiatan lanjutan dengan tahapan lang lebih baik dan pengetahuan yang lebih banyak. Mengingat pentingnya materi ini untuk para pendidik PAUD, kegiatan ini sebaiknya dilakukan dalam skala yang lebih besar dan menjangkau lebih banyak pendidik PAUD di seluruh Indonesia. Hal ini dapat dikaitkan dengan 4 langkah pelatihan menurut Kirkpatrick (2006), artinya pelatihan dilakukan dalam jangka waktu beberapa hari

\section{DAFTAR PUSTAKA}

[1] Abdurrahman, M dan Sudjadi, S. 1994. Pendidikan Luar Biasa Umum. Jakarta: Depdikbud Ditjen Dikti.

[2] Fitriani, dkk. 2011. Motif Keterlibatan Kaum Ibu dalam Pendidikan Anak Usia Dini di Jakarta Barat. Jurnal Al Azhar Indonesia Seri Humaniora Vol 1 no 1 Maret 2011

[3] Hardjomarsono, B. 2007. Teori dan Metode Intervensi Sosial. Edisi 2. Buku Materi Pokok. Jakarta : Penerbit Universitas Terbuka

[4] http://edisicetak.joglosemar.co/berita/pen didikan-anak-berkebutuhan-khusus249000-orang-belum-tersentuh- 10611.html. (Diakses pada 28 September 2014)

[5] http://www.kemdikbud.go.id/kemdikbud/b erita/2655. (Diakses pada 29 September 2014)

[6] http://www.kemdikbud.go.id/kemdikbud/b erita/2060. (Diakses pada 29 September 2014)

[7] http://poskotanews.com/2013/07/18/jumla h-abk-makin-banyak/. (Diakses pada 28 September 2014)

[8] http://poskotanews.com/2013/07/20/kenal i-anak-berkebutuhan-khusus-sejak-dinil

(Diakses pada 29 September 2014)

[9] http://poskotanews.com/2013/07/19/jumla h-anak-berkebutuhan-khusus-meningkat/ (Diakses pada 29 September 2014)

[10] http://republiknews.com/apk-paud-setiaptahun-terus-meningkat/. (Diakses pada 29 September 2014)

[11] http://www.republika.co.id/berita/nasiona l/umum/13/07/17/mq2zvp-jumlah-anakberkebutuhan-khusus-di-indonesia-tinggi, (Diakses pada 28 September 14)

[12] KirkPatrick, DL; \& Kirkpatrick, JD. 2006. Evaluating Training Programs, 3rd edition. Berret-Koehler Publisher, SanFrancisco

[13] Mangunsong, F. 2008. Psikologi dan Pendidikan Anak Berkebutuhan Khusus. Jilid 1. LPSP3 UI Depok

[14] NSPK Juknis Penyelenggaraan Pos PAUD, Kementerian Pendidikan dan Kebudayaan, Direktorat Jenderal Pendidikan Anak Usia Dini, Non Formal dan Informal Direktorat Pendidikan Anak Usia Dini, 2013

[15] Panduan Penanganan Anak Berkebutuhan Khusus Bagi Pendamping (Orang tua, Keluarga, dan Masyarakat) ,Kementerian Pemberdayaan Perempuan dan Perlindungan Anak Republik Indonesia, Jakarta, 2013

[16] Permeneg PP\&PA No.10 Thn 2011 Tentang ABK, diakses tanggal 28 September 2014

[17] Sanytiasa, B. 2014. Upaya Meningkatkan Kemampuan Menulis Anak Usia 5-6 
Tahun Melalui Bermain Play Dough Di RA Apel Cilandak Timur. Skripsi. Universitas Al Azhar Indonesia Jakarta, tidak diterbitkan
[18] Sugiyono. 2013. Metode Penelitian Pendidikan (Pendekatan Kuantitatif, Kualitatif, dan R\&D). Bandung: Alfabeta. 


\section{Lampiran 1}

Paired Samples Statistics

\begin{tabular}{|rr|r|r|r|r|}
\hline & & Mean & N & Std. Deviation & Std. Error Mean \\
\hline \multirow{2}{*}{ Pair 1 } & Pretest & 68.78 & 37 & 17.297 & 2.844 \\
& Postest & 90.68 & 37 & 9.141 & 1.503 \\
\hline
\end{tabular}

\section{Lampiran 2}

\section{Paired Samples Correlations}

\begin{tabular}{|ll|r|r|r|}
\hline & $\mathrm{N}$ & Correlation & \multicolumn{1}{c|}{ Sig. } \\
\hline Pair 1 Pretest \& Postest & 37 & .629 & .000 \\
\hline
\end{tabular}

\section{Lampiran 3}

Paired Samples Test

\begin{tabular}{|c|c|c|c|c|c|c|c|c|c|}
\hline & & \multicolumn{5}{|c|}{ Paired Differences } & \multirow[t]{3}{*}{$t$} & \multirow[t]{3}{*}{$d f$} & \multirow{3}{*}{$\begin{array}{l}\text { Sig. (2- } \\
\text { tailed) }\end{array}$} \\
\hline & & \multirow[t]{2}{*}{ Mean } & \multirow[t]{2}{*}{$\begin{array}{c}\text { Std. } \\
\text { Deviation }\end{array}$} & \multirow[t]{2}{*}{$\begin{array}{c}\text { Std. Error } \\
\text { Mean }\end{array}$} & \multicolumn{2}{|c|}{$\begin{array}{c}\text { 95\% Confidence } \\
\text { Interval of the } \\
\text { Difference }\end{array}$} & & & \\
\hline & & & & & Lower & Upper & & & \\
\hline Pair 1 & $\begin{array}{l}\text { Pretes } \\
\mathrm{t} \text { - } \\
\text { Postes } \\
\mathrm{t}\end{array}$ & -21.892 & 13.558 & 2.229 & -26.412 & -17.371 & -9.822 & 36 & .000 \\
\hline
\end{tabular}

